\title{
Childhood Female Hydrocele Presenting in Adulthood
}

\author{
Ankit Shukla ${ }^{1}$, Varun Verma ${ }^{1}$, Roshni Shukla ${ }^{2}$, Rajesh Chaudhry ${ }^{3 *}$, Nishant Nayyar ${ }^{1}$ and Krishan Lal Kapoor ${ }^{1}$ \\ ${ }^{1}$ Civil Hospital Palampur, India
}

${ }^{2}$ Department of Radiology, India,

${ }^{3}$ Department of General Surgery, India

Received: February 02, 2018; Published: March 21, 2018

*Corresponding author: Rajesh Chaudhary, Senior Resident, Department of General Surgery, Dr Rajendra Prasad Government Medical College, India, Email: topgun.chaudhary@gmail.com

\section{Abstract}

Female hydrocele or hydrocele of canal of Nuck is a very rare entity, resulting from failure of obliteration of the canal and accumulation of fluid within it, usually seen in infancy and adolescence but rarely in adulthood. There is paucity of cases of female hydrocele in the literature and even more less cases are seen in adulthood. We present a rare case of hydrocele of canal of Nuck in an adult lady dealt successfully with surgery in a secondary care institute.

\section{Introduction}

In females, canal of Nuck is akin to processus vaginalis in males, which usually gets obliterated by the first birthday. Failure to attain total obliteration of the canal leads to formation of indirect inguinal hernia or hydrocele of canal of Nuck, which is synonymous to the term female hydrocele or cyst of the canal of Nuck. It is a very rare entity and only 400 cases are reported in the literature all over the globe [1]. Most common type of female hydrocele or hydrocele of canal of Nuck is similar to encysted hydrocele in males extending from indirect ring to vulva without any communication with the peritoneal cavity. Other types include, hydrocele having communication with the peritoneal cavity similar to congenital hydrocele in males and bilocular hydrocele with constriction at the deep ring.

\section{Case Report}

A young female of 38 years presented to our secondary care institute with a history of painless swelling in the right groin since last ten years, which had increased in size in recent times with no history suggestive of obstruction or trauma. On physical examination the swelling was irreducible, non tender, soft, cystic measuring about $5 \mathrm{~cm}$ in length and $3 \mathrm{~cm}$ in width and without any cough impulse. Patient was subjected to Ultrasonography which revealed a hypoechoic sausage shaped cystic lesion in the right inguinal region suggestive of hydrocele of canal of Nuck or a lyphangioma. Patient was planned for surgery and on exploration a cystic swelling, without communication with the peritoneal cavity or indirect hernia, was found having a dark brown fluid in it and measuring $5 \mathrm{~cm}$ in length and $2 \mathrm{~cm}$ in width extending from the deep ring up to the pubic tubercle, which was separated carefully and excised with ligation at the deep ring (Figure 1).

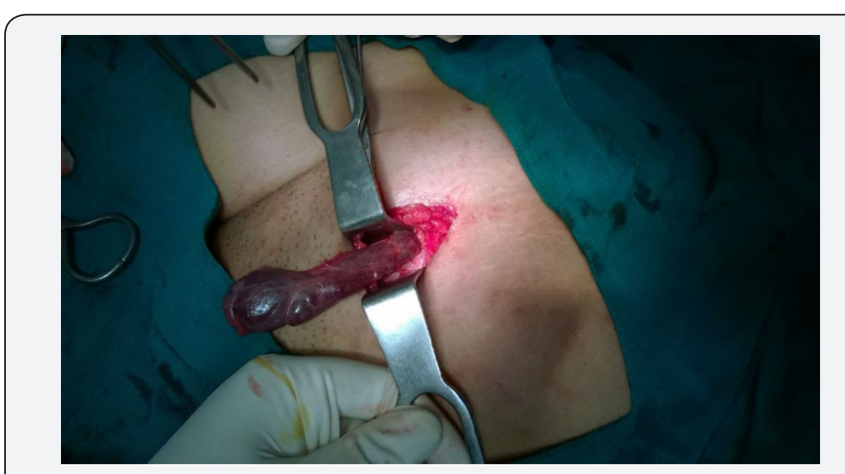

Figure 1: Hydrocele of canal of Nuck.

Postoperative period was uneventful and patient was discharged on fifth post operative day and was followed up for one year with no evidence of recurrence.

\section{Discussion}

First description of canal of Nuck was given in 1691, by Anton Nuck also known as Antonius Nuck van Lieden, a Dutch anatomist, oculist, aurist and dentist. [2] In the year 1892, Coley an American surgeon reported fourteen cases of hydrocele of 
canal of Nuck with a comprehensive review of literature. [3]There is paucity of cases and literature on female hydrocele and only around four hundred reported case worldwide. [1] Congenital hydrocele in boys is seen frequently, whereas a hydrocele is rarely seen in girls and even rarer in adult females. In females the round ligament of the uterus, a derivative of the caudal end of the guberbaculum, descends from the cornu passing through the inguinal canal and inserting into the labia major.

A finger like invagination of the parietal peritoneum passing along with the round ligament forms the canal of Nuck. This canal of Nuck in females, which is analogous to processus vaginalis in males, gets obliterated by first year and its failure to obliterate results in formation of hydrocele of canal of Nuck or indirect inguinal hernia [4]. Histiologically the canal of Nuck consists of two layers, an outer layer of a fibrous tissue having fibers of smooth muscle andan inner single cell layer of mesothelial cells. Female hydrocele results due to imbalance of secretion and absorption by the single cell inner layer mesothelial cells [5]. This imbalance of secretion and absorption is the fall out of infection, trauma or most commonly idiopathic [6].

The female hydrocele or the hydrocele of the canal of Nuck is classified into three types. The first type has no communication with the peritoneal cavity and is the most common type, which corresponds to the encysted hydrocele of males and the hydrocele can be located anywhere from the deep ring to the labia major. The case described above resembles this most common type. The second type has a communication with peritoneal cavity, which corresponds to the congenital hydrocele of the males. The third and the last type has a constriction at the deep ring giving rise to bilocular or hour glass type of hydrocele. The upper sac lies extraperitoneally and the lower sac in the canal and can be mistaken as a reducible hernia $[3,7]$.

The diagnosis of type one hydrocele of the canal of Nuck is established on the basis of clinical examination and history of a non reducible, painless cystic swelling in the groin or the labia major, which transilluminates and has no cough impulse unless associated with an indirect inguinal hernia, which happens to be seen in thirty to forty percent of cases. The clinical diagnosis is also a difficulty in obese patients. The second type has a non tender reducible swelling, which may have a cough impulse. In hour glass type clinical diagnosis is difficult to establish and it is mostly misdiagnosed as a hernia. The differential diagnosis includes inguinal hernia, lymphangioma, abscess, pseudo aneurysm, bartholin's cyst. Endometriosis of round ligament, lipoma, sarcoma and lymphadenopathy $[3,8,9]$. The first investigation done in a groin swelling in a female is ultrasonography. In hydrocele of canal of Nuck on ultrasonography with a high frequency linear array reveals a sausage shaped mass along with the round ligament, which may be hypoechoic or anechoic and with or without septations [9]. Magnetic resonance imaging has also been included in the armamentarium for investigating these cystic swellings.
Advantage of MRI is that it gives exact anatomical relation with the adjoining structures and the precise extent of these thin walled cystic swellings.

The hydrocele of canal of Nuck appears as hyper intense on T2 weighted images and hypo intense on T1 weighted images $[2,10]$. Computed tomography images show a thin walled cystic swelling in the inguinal region and can also appreciate the septations [1]. Mainstay of the treatment of hydrocele of canal of Nuck is surgery with hydrocelectomy and high ligation at the deep ring to prevent recurrence. An attractive option is aspiration of the fluid with or without ultrasound guidance; however this approach seems to have high recurrence rate. Female hydrocele associated with inguinal hernia and the bilocular hydroceles have been dealt with laparoscopically on a few occasions and reported in the literature [11].

\section{Conclusion}

In the recent times there has been a slight rise in reporting of female hydrocele, however due to paucity of literature many surgeons are unfamiliar with this entity which is an important differential in the inguinolabial swellings. Preoperative clinical diagnosis is seldom established and ultrasonography, MRI and computed tomography aid in reaching the diagnosis. The most effective way to deal with female hydrocele is hydrocelectomy with high ligation.

\section{References}

1. Sethi V, Patel H (2016) Hydrocele in the Canal of Nuck-CT appearance of a developmental groin anomaly. J Radiol Case Rep 10(11): 29-33.

2. Kono R, Terasaki H, Murakami N, Tanaka M, Takeda J, et al. (2015) Hydrocele of the canal of Nuck: a case report with magnetic resonance hydrography findings. Surgical Case Reports 1: 86.

3. Coley WB (1892) Hydrocele in the female with report of fourteen cases. Ann Surg 16(1): 42-59.

4. Mandhan P, Raouf Z, Bhatti K (2013) Infected hydrocele of the canal of Nuck. Case Reports in Urology 275257.

5. Kim KS, Choi JH, Kim HM, Kim KP, Kwon YJ, et al. (2016) Hydrocele of the canal of Nuck in a female adult. Arch Plast Surg 43(5): 476-478.

6. Dagur G, Gandhi J, Suh Y, Weissbart S, Sheynkin YR, et al. (2017) Classifying hydroceles of the pelvis and groin: an overview of etiology, secondary complications, evaluation, and management. Curr Urol 10(1): 1-14.

7. Sarkar S, Panja S, Kumar S (2016) Hydrocele of the canal of Nuck (Female Hydrocele): a rare differential for inguino-labial swelling. J Clin Diagn Res 10(2): PD21-PD22.

8. Caviezel A, Montet X, Schwartz J, Egger JF, Iselin CE (2009) Female hydrocele: the cyst of Nuck. Urol Int 82(2): 242-245.

9. Kaeser MA, Haun DW, Cho JS, Kettner NW (2011) Hydrocele in the canal of Nuck. Journal of Medical Ultrasound 19(4): 138-140.

10. Manjunatha YC, Beeregowda YC, Bhaskaran A (2012) Hydrocele of the canal of Nuck: imaging findings. Acta Radiol Short Rep 1(3): 12-15.

11. Qureshi NJ, Lakshman K (2014) Laparoscopic excision of cyst of canal of Nuck. J Minim Access Surg 10(2): 87-89. 


\section{Your next submission with Juniper Publishers} will reach you the below assets

- Quality Editorial service

- Swift Peer Review

- Reprints availability

- E-prints Service

- Manuscript Podcast for convenient understanding

- Global attainment for your research

- Manuscript accessibility in different formats

( Pdf, E-pub, Full Text, Audio)

- Unceasing customer service

Track the below URL for one-step submission https://juniperpublishers.com/online-submission.php 